\title{
Application of Fracture Barrier Analysis in Well Stimulation Planning for Upper Baturaja Limestone Formation Based on Well Log \& Drill Cutting Data from OBF-01 and OBF-04 Wells, Offshore Southeast Sumatra
}

\author{
Aris Buntoro ${ }^{1 *)}$, Muhammad Nurcholis2 ${ }^{*}$, Basuki Rahmad ${ }^{2 *)}$, Allen Haryanto $\mathbf{L}^{1 *)}$, Ristiyan $\operatorname{Ragil}^{\left.1^{*}\right)}$ \\ 1) Petroleum Engineering Department, Faculty of Mineral Technology, UPN “Veteran” Yogyakarta \\ 2) Soil Science, Faculty of Agriculture, UPN "Veteran" Yogyakarta \\ 3) Geology, Faculty of Mineral Technology, UPN "Veteran” Yogyakarta \\ * corresponding email: arisbuntoro@upnyk.ac.id
}

\begin{abstract}
In general, the South Sumatra Regional Stratigraphy of the Baturaja Limestone Formation facies is deposited on the Buildup Carbonate (Reef) and the Limestone Clastic Carbonate of the Baturaja Formation which grows as a buildup reef on the platform in the Basement High (Horst) underneath is the Lemat Formation volcanic deposits. Referring to the facies model in general, the Baturaja Limestone Formation, the depositional environment starts from Shelf Lagoon Open Circulation - Winnowed Edge Sand - Organic Buildup - Fore Slope - Deep Shelf Margin - Open Sea Shelf - Basin, meaning that carbonate is formed starting from pure organic Cabonate Buildup Reef without / a little sludge / mud to the Carbonate Basin where more muddy / mud is present, this condition causes clay minerals to also more and more mix with Terigenous Clastics (Quartz, feldpar). The complexity of the Baturaja Limestone Formation requires fracture barrier analysis associated with well stimulation planning in order to increase oil productivity with the appropriate method. Fracture barrier fracture analysis is an approach method to determine the depth interval that becomes a barrier in hydraulic fracturing by correlating the results of geomechanical analysis from well log data and mineralogical analysis from drill cuttings data, so that a commonly used well stimulation method can be selected, namely hydraulic fracturing, acidizing, and acid-fracturing.

From the ternary diagram plot the XRD (bulk) analysis results show that the distribution of the main minerals (Quartz, Clay, Calcite) is more dominant in the ductile zone, hard to frac category. This shows that all the depth intervals in the OBF-01 and OBF-04 wells are more ductile, and are not recommended for hydraulic fracturing. From the XRD (bulk) analysis, Calcite mineral is more dominant, so for well stimulation work it is recommended to use acidizing or acidfracturing.
\end{abstract}

Keywords: baturaja limestone formation, drill cuttings, fracture barrier, well log, well stimulation

\section{INTRODUCTION}

The South Sumatra Basin is one of four basins located on the back side of the Sumatra portion of the Indonesian Island Arc complex. It consists of several structural sub-basins with Tertiary sedimentary section lying unconformably on the eroded and faulted topography of Pre-Tertiary basement metamorphic and igneous rocks. Late Tertiary anticlinal traps account for more than $75 \%$ of the known oil and gas reserves in the province (Hall, 2002).

Baturaja carbonate deposition within the study area began during the early Miocene at the onset of the marine transgression that followed the Eocene rifting phase. Throughout the area, the Baturaja carbonates appear to unconformably overlie the marine shales of the Pendopo Formation, the terrestrial deposits of the Talang Akar formation and the Pre-Tertiary age basement. Downdip, the Pendopo Formation appears to transition directly into the basal carbonates of the Baturaja formation, making it difficult to define the transition between the formations.

There are seven depositional environments were defined using the relative position of the well within the platform and the dominant lithofacies derived from log-based facies tied up to both core and mud log descriptions: Buildup/Reef; Fore reef/flank; Shoal; Sand/Mud Aprons; Platform Interior; Lagoon; and Basin The BRF carbonates had two distinct development stages: the initial basal transgressive phase and the final highstand phase. Carbonate buildup development took place along the platform margin during the initial basal transgressive phase and moved into the surrounding basement highs areas during the highstand phase (Sanchez \& Danudjaja, 2013).

Referring to the facies model (Wilson, 1975) in general, the Baturaja Limestone Formation, the depositional environment starts from: Shelf Lagoon Open Circulation - Winnowed Edge Sand - Organic Buildup - Fore Slope - Deep Shelf Margin - Open Sea Shelf - Basin, meaning that carbonate is formed starting from Pure Organic Kabonate Buildup Reef without / 
less mud / mud to Carbonate Basin where more muddy / mud is present, this condition causes clay minerals to also mix more and more with Terigenous Clastics (Quartz, feldpar).

In an effort to increase hydrocarbon production from reservoir rocks with low permeability, information is needed about the elastic properties of the rock (geomechanical parameters) as a basis for determining formation intervals with high fracability (Jin et al., 2014; Sui et al., 2015; Bai, 2016), so a geomechanical analysis is needed to model the interval of prospect formation with high fracability using well log data (Lobo et al., 2017). Fracability is a function of the brittleness index which can be calculated from Young's Modulus and Poisson's ratio (Grieser and Bray, 2007; Yuan et al., 2017).

Sui et al. (2015) stated that fracability is a comprehensive reflection of geological and reservoir characteristics, especially those related to crustal stress, rock brittleness, brittle mineral content, clay content, rock strength, digenesis and natural fracture, where fracability is a term currently used in choose hydraulic fracturing interval.

Previously, many argued that only brittleness could characterize natural fracture rock, assuming that formations with high brittleness would break easily (Sui et al., 2015). Chong et al. (2010) stated that brittleness alone is not sufficient to describe fracability, because formations with higher brittleness can also be a fracture barrier.

High-brittleness formations are considered as good candidates for hydraulic fracturing. However, this point of view is not entirely correct, because brittleness does not indicate rock strength (Jin et al., 2014; Jinbu, 2015). This can be found in the case of barrier faults between the upper and lower Shale Barnett formations, namely the presence of dolomite limestones from the Forestburg formation with higher brittleness, but instead become a fault barrier (Jin et al., 2014). To overcome the weaknesses of the high brittleness criteria in determining the hydraulic fracturing interval, the fracability index (FI) parameter was introduced, namely by integrating brittleness and energy absorption during hydraulic fracturing.

Thus, from the results of the fracture barrier analysis of the Baturaja limestone formation from the OBF-01 and OBF-04 wells of Offshore Southeast Sumatra using drill cuttings and well log data, a fracability model can be made that can be applied to determine the location and formation depth intervals in well stimulation planning accurately.

\section{METHODS}

\subsection{Geological Setting of the South Sumatra Basin}

The South Sumatra Basin formation has been divided in three major tectonic phases: 1) Eocene Tectonic extension, 2) Tectonic quiescence with late normal faulting from early Miocene to early Pliocene and 3) Basement compression and basin inversion since the Pliocene (Bishop, 2001). The extensional phase started in the Eocene with the rifting of PreTertiary basement resulting in a series of half-grabens that were later filled by locally derived, syn-sedimentary deposits of Eocene-Early Miocene age. Tectonic quiescence and crustal cooling during the Early Miocene to Early Pliocene, along with the onset of a widespread marine transgression, provided the ideal conditions for carbonate deposition during the second tectonic phase. Compression and inversion of the basin began in Pliocene time (Bishop, 2001).

Baturaja limestone formation was deposited during the transition of the rifting stage and tectonic quiescence specifically in the early Miocene time. The Baturaja Formation carbonate facies in Letang, Rawa, and Tengah could be divided into two main units, which are the muddy wackestone/packstone platform facies and coral-algal floatstone/boundstone reefal facies. The platform facies predominantly consist of tight muddy wackestone to packstone distributed predominantly across the area with various thickness ranges from $5-100$ meters, with the porosity of this unit ranges from $0-12 \%$. The facies represent the early transgressive sequence and consists of carbonate basal layer unconformably overlying the syn-rift terrestrial-marine sediments and Pre-Tertiary basement rocks (Amir, et al., 2011).

The Baturaja limestone formation in general was deposited in the back-reef environment behind the edge of the basin during the Early Miocene (Maryanto, 2007).

Regional Stratigraphy of South Sumatra (Pujasmadi, 2002) in general, the Baturaja limestone formation facies are deposited in Buildup Carbonate (Reef) and Limestone Clastic Carbonate of the Baturaja formation which grows as buildup reef on the platform in Basement High (Horst) underneath is the Lemat Formation Volcanic Deposits. This data is strengthened by a seismic cross section (Sanchez \& Danudjaja, 2013).

\subsection{Literature Review}

The types of minerals contained in rock samples can be identified using XRD (X-Ray Diffraction) analysis with the bulk method, and the result is that the peaks can be read by the type of mineral based on the determinant peaks (Bladh et al., 2001), and can be categorized into two groups, namely the major minerals and minor minerals. From the results of the 
main minerals, i.e: Quartz, Clay, and Carbonate (Q-C-C), the brittleness index can be determined using the Jarvie Equation (2007), as follows:

$$
B I_{(J a r v i e, 2007)}=\frac{W_{q t z}}{W_{t}}
$$

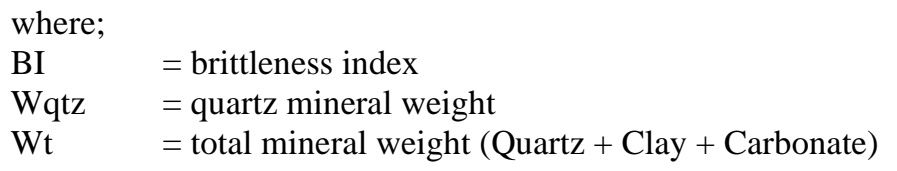

The brittleness index is the most widely used parameter to measure the brittleness of rocks (Perez and Marfurt, 2013). In general, brittleness is used as a descriptor in selecting formation depth intervals for hydraulic fracturing planning, so brittleness is one of the most important rock mechanical properties (Jarvie et al., 2007, Chong et al., 2010; Jinbu et al., 2015).

Sonic Log is a logging tool that is used to determine the mechanical properties of rocks, the principle of which works is to use sound speed waves that are sent or transmitted into the formation by the transmitter, where the reflected sound will be received by the receiver. The time it takes for sound waves to reach the receiver is known as the transit time interval $(\Delta t)$. When these waves travel through rock samples, different wave types also experience different attenuation. During experimental measurements, S-waves are more difficult to obtain, so for most applications P-waves are used frequently. However, the determination of S-waves is very important for calculating the modulus of elasticity (E) or Young's Modulus and Poisson's ratio.

The dynamic compressive strength of rocks can be determined using empirical equations obtained from P-wave velocity data (sonic log data) with equations from Kahraman (2007) for dolomite, sandstone, marl, limestone, shale, diabase and serpentinite rocks.

$$
\mathrm{UCS}=9.95 \times \mathrm{V}_{\mathrm{P}}^{1.21}
$$

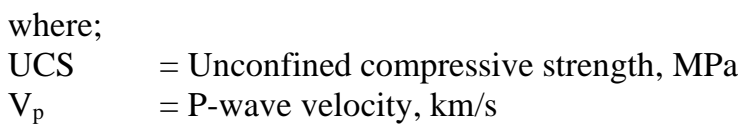

Dynamic Young's modulus of rocks can be determined using empirical equations obtained from the P-wave velocity and S-wave velocity data. With the limited data from Sonic Log, which only has a P-waves velocity value, it is therefore assumed that the $\mathrm{S}$-waves value is based on the Castagna equation (1985). Castagna plotted Vp and Vs in the dominant Shale formation, resulting in the following equation:

$$
\mathrm{V}_{\mathrm{s}}=0.862 \mathrm{~V}_{\mathrm{p}}-1.172
$$

with dynamic Young's Modulus equation proposed by Fjær et al. (2008):

$$
\mathrm{E}=\rho V_{s}^{2} \frac{\left(3 V_{p}^{2}-4 V_{s}^{2}\right)}{\left(V_{p}^{2}-V_{s}^{2}\right)}
$$

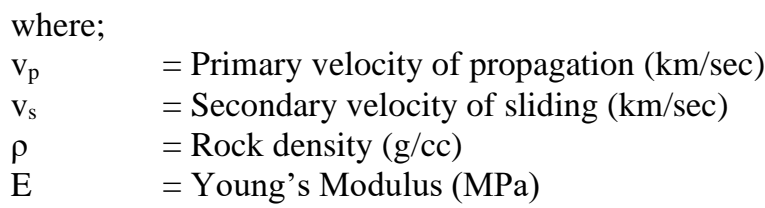

Dynamics Poisson's ratio of rock can be determined using empirical equations obtained from P-wave velocity and S-wave velocity data with the equation according to Zoback (2007):

$$
v=\frac{1-2\left[\frac{v_{s}}{v_{p}}\right]^{2}}{2\left[1-\left[\frac{v_{s}}{v_{p}}\right]^{2}\right]} \quad \text { or } \quad v=\frac{V_{p}^{2}-2 V_{s}^{2}}{2\left(V_{p}^{2}-V_{s}^{2}\right)}
$$

where;

$\mathrm{v}_{\mathrm{p}} \quad=$ Primary velocity of propagation $(\mathrm{km} / \mathrm{sec})$ 


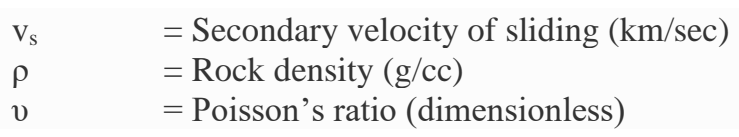

The Young's modulus of brittleness ( $\left.\mathrm{E}_{\text {brittleness }}\right)$ will have a value between $0-1$, where the higher the modulus young value or approaching the maximum value of the modulus young rock calculation in a well with Equation 6, the rock will be brittle and vice versa, where the $\mathrm{E}_{\max }$ value is obtained from the calculation results. The highest modulus young from the calculation of the well $\mathrm{log}$, on the other hand, $\mathrm{E}_{\min }$ is obtained from the lowest modulus young calculation from the well $\log$ calculation as in Figure 1, so that the determination of the modulus young brittleness can be determined by the equation:

$$
\mathrm{E}_{\text {brittleness }}=\frac{\mathrm{E}-\mathrm{E}_{\min }}{\mathrm{E}_{\max }-\mathrm{E}_{\min }}
$$

$$
\begin{array}{ll}
\text { where; } & \\
E_{\text {brittleness }} & =\text { Young's modulus of brittleness, frction } \\
\mathrm{E} & =\text { Young's modulus, MPa } \\
\mathrm{E}_{\min } & =\text { Minimum Young's modulus, MPa } \\
\mathrm{E}_{\max } & =\text { Maximum Young's modulus, MPa }
\end{array}
$$

The Poisson's ratio of brittleness ( $v_{\text {brittleness}}$ ) will be between 0 - 1 where the lower the Poisson's ratio value or close to the minimum value of the rock Poisson's ratio calculation with Equation 7, the rock will be brittle and vice versa, where the $v_{\max }$ value is obtained from the highest Poisson's ratio calculation. From the calculation, on the contrary, $\mathrm{U}_{\min }$ is obtained from the lowest Poisson's ratio calculation as in Figure 1 so that the Poisson's ratio of brittleness can be determined by the equation:

$$
v_{\text {brittleness }}=\frac{v-v_{\max }}{v_{\min }-v_{\max }}
$$

where;

$v_{\text {brittleness }}=$ Poisson's ratio of brittleness, fraction

$\begin{array}{ll}v & =\text { Poisson's ratio, fraction } \\ v_{\min } & =\text { Minimum Poisson's ratio, fraction } \\ v_{\max } & =\text { Maximum Poisson's ratio, fraction }\end{array}$

So, the brittleness average can be determined by averaging the $\mathrm{E}_{\text {brittleness }}$ and $v_{\text {brittleness }}$ with the equation:

$$
\mathrm{B}_{\mathrm{avg}}=\frac{\mathrm{E}_{\text {brittleness }}{ }^{\mathrm{v}} \text { brittleness }}{2}
$$

where;

$$
\begin{array}{ll}
\mathrm{B}_{\text {avg }} & =\text { Brittleness Average, fraction } \\
v_{\text {brittleness }} & =\text { Poisson's ratio of brittleness, fraction } \\
\mathrm{E}_{\text {brittleness }} & =\text { Young's Modulus of brittleness, fraction }
\end{array}
$$

Perez and Marfurt (2013) in their paper proposed the category of rock brittleness based on the brittleness index value as shown in Table-1.

Table 1. Rocks brittleness category based on the brittleness index (Perez and Marfurt, 2013)

\begin{tabular}{ccc}
\hline No & Brittleness Index & Category \\
\hline 1 & $0-0.16$ & Ductile \\
2 & $0.16-0.32$ & Less ductile \\
3 & $0.32-0.48$ & Less brittle \\
4 & $>0.48$ & Brittle \\
\hline
\end{tabular}

Fracability is defined as a measure of the ease a formation can be broken. This parameter is a parameter that needs to be determined if hydraulic fracturing is to be performed in the reservoir rock to increase rock permability. Jin et al. (2014) 
classified rock types based on the value of the fracability index, based on the relationship between Brittleness and Young's modulus as shown in Table 2.

Table 2. Classification of Rock Types Based on the Fracability Index (Jin et al., 2014)

\begin{tabular}{clc}
\hline No & \multicolumn{1}{c}{ Rock Type } & $\begin{array}{c}\text { Fracabilty Index } \\
\text { (dimensionless) }\end{array}$ \\
\hline 1 & Fracable & $>0.55$ \\
2 & Not Fracable (hard to frac) & $\leq 0.55$ \\
\hline
\end{tabular}

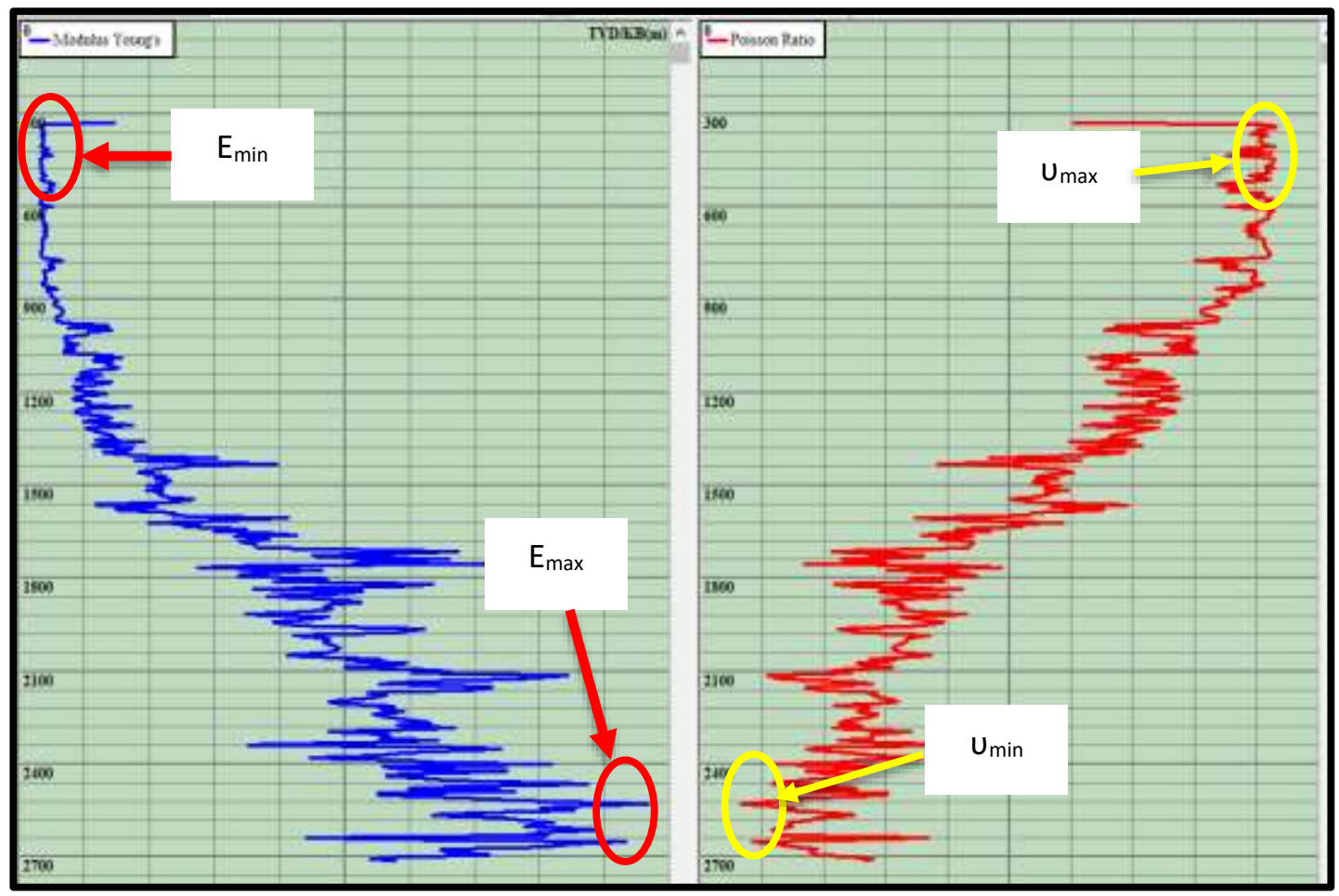

Figure 1. Determination of Maximum-Minimum Young Modulus and Poisson's Ratio Maximum-Minimum

Based on the Table 2, rocks can easily crack or break if it has a fracability index value greater than 0.55. Meanwhile, rocks will not easily crack or be difficult to break if they have a fracability index value of less than or equal to 0.55 .

The mathematical model of the fracability index can be determined based on the parameters of Brittleness and Young's Modulus which are defined as follows:

$\mathrm{FI}=\frac{\mathrm{B}_{\mathrm{n}}+\mathrm{E}_{\mathrm{n}}}{2}$

where;

FI $\quad=$ Fracability index, fraction

$\mathrm{B}_{\mathrm{n}} \quad=$ Brittleness normalization, fraction

$\mathrm{E}_{\mathrm{n}} \quad$ = Young's Modulus normalization, fraction

Normalization of the brittleness index can be determined by the equation:

$\mathrm{B}_{\mathrm{n}}=\frac{\mathrm{B}-\mathrm{B}_{\min }}{\mathrm{B}_{\max }-\mathrm{B}_{\min }}$

where;

$\mathrm{B}_{\mathrm{n}} \quad=$ Brittleness normalization, fraction

$\mathrm{B}=$ Brittleness at analyzed depth, fraction

$\mathrm{B}_{\min }=$ Minimum brittleness in formation is investigated, fraction

$\mathrm{B}_{\max }=$ Maximum brittleness in formation is investigated, fraction 
Normalization of Young's modulus can be determined by the equation:

$$
E_{n}=\frac{E_{\max }-E}{E_{\max }-E_{\min }}
$$

where;

$\mathrm{E}_{\mathrm{n}} \quad$ = Young's Modulus normalization, fraction

$\mathrm{E} \quad=$ Young's Modulus at anlayzed depth, $\mathrm{MPa}$

$\mathrm{E}_{\text {min }}=$ Minimum Young's Modulus in formation is investigated, $\mathrm{MPa}$

$\mathrm{E}_{\max }=$ Maximum Young's Modulus in formation is investigated, $\mathrm{MPa}$

\section{RESULTS AND DISCUSSION}

\subsection{XRD (bulk) analysis results of the OBF-01 and OBF-04 wells}

XRD (bulk) analysis to identify the main mineral types contained in each of the drill cutting samples from wells OBF-01 and OBF-4. Mineral types identified from the XRD analysis using the bulk powder method, i.e: 8 samples from Well OBF-01, and 8 samples from Well OBF-4 are shown in Table 3 and Table 4.

From the results of the bulk analysis of the drill cutting samples of the OBF-01 and OBF-04 wells, a plot of the main minerals (Quartz, Clay and Calcite) was carried out with the ternary diagram shown in Figure 2. From Figure 2, it can be seen that the distribution of main minerals (Quartz, Clay, and Calcite) is more dominant in Zone 4 (Ductile, hard to frac category). This shows that all the depth intervals in the OBF-01 and OBF-04 wells are more ductile, so hydraulic fracturing is not recommended. From the results of the bulk analysis, Calcite mineral is more dominant, so for well stimulation work it is recommended to use acidizing or use acid fracturing. 
Table 3. XRD (bulk) analysis results of drill cutting samples of well OBF-01

\begin{tabular}{|c|c|c|c|c|c|c|c|c|c|c|c|c|}
\hline \multirow[b]{2}{*}{ No } & \multicolumn{4}{|c|}{ Main Mineral } & \multicolumn{7}{|c|}{ Minor Mineral } & \multirow[b]{2}{*}{$\begin{array}{c}\text { Total } \\
(\%)\end{array}$} \\
\hline & Depth (ft) & Quartz (\%) & Calcite(\%) & Clay (\%) & $\begin{array}{c}\text { Feldspar } \\
\text { (\%) }\end{array}$ & $\begin{array}{l}\text { Apatite } \\
(\%)\end{array}$ & Pyrite (\%) & $\begin{array}{c}\text { Dolomite } \\
\text { (\%) }\end{array}$ & $\begin{array}{c}\text { Sillimanite } \\
\text { (\%) }\end{array}$ & $\begin{array}{c}\text { Kaliophilite } \\
\text { (\%) }\end{array}$ & $\begin{array}{c}\text { Epidote } \\
(\%)\end{array}$ & \\
\hline 1 & 5120 & 25,92 & 19,42 & 31,15 & 9,41 & 3,43 & 3,77 & 0,00 & 0,00 & 0,00 & 6,89 & 100 \\
\hline 2 & 5180 & 25,43 & 36,74 & 24,37 & 0,00 & 0,00 & 3,82 & 0,00 & 0,00 & 0,00 & 9,65 & 100 \\
\hline 3 & 5200 & 21,77 & 35,13 & 25,14 & 3,14 & 0,00 & 3,29 & 2,85 & 0,00 & 0,00 & 8,66 & 100 \\
\hline 4 & 5220 & 64,66 & 14,51 & 15,71 & 0,00 & 0,00 & 1,81 & 0,00 & 0,00 & 0,00 & 3,31 & 100 \\
\hline 5 & 5240 & 26,91 & 37,00 & 22,99 & 0,00 & 0,00 & 3,79 & 0,00 & 0,00 & 0,00 & 9,31 & 100 \\
\hline 6 & 5260 & 25,60 & 33,22 & 24,01 & 7,16 & 0,00 & 3,92 & 0,00 & 0,00 & 0,00 & 6,09 & 100 \\
\hline 7 & 5280 & 20,82 & 38,88 & 16,42 & 16,27 & 0,00 & 2,34 & 0,00 & 0,00 & 0,00 & 5,27 & 100 \\
\hline 8 & 5328 & 32,80 & 36,23 & 19,68 & 0,00 & 0,00 & 2,90 & 0,00 & 0,00 & 0,00 & 8,39 & 100 \\
\hline
\end{tabular}

Table 4. XRD (bulk) analysis results of drill cutting samples of well OBF-04

\begin{tabular}{|c|c|c|c|c|c|c|c|c|c|c|c|c|}
\hline \multirow[b]{2}{*}{ No } & \multicolumn{4}{|c|}{ Main Mineral } & \multicolumn{7}{|c|}{ Minor Mineral } & \multirow{2}{*}{$\begin{array}{l}\text { Total } \\
(\%)\end{array}$} \\
\hline & Depth (ft) & Quartz (\%) & Calcite(\%) & Clay (\%) & $\begin{array}{c}\text { Feldspar } \\
(\%)\end{array}$ & $\begin{array}{c}\text { Apatite } \\
\text { (\%) }\end{array}$ & Pyrite (\%) & $\begin{array}{c}\text { Dolomite } \\
(\%)\end{array}$ & $\begin{array}{c}\text { Sillimanite } \\
\text { (\%) }\end{array}$ & $\begin{array}{c}\text { Kaliophilite } \\
(\%)\end{array}$ & $\begin{array}{c}\text { Epidote } \\
(\%)\end{array}$ & \\
\hline 1 & 5160 & 28,97 & 19,15 & 34,34 & 4,83 & 0,00 & 3,32 & 3,17 & 0,00 & 0,00 & 6,21 & 100 \\
\hline 2 & 5188 & 31,98 & 18,19 & 30,93 & 6,81 & 0,00 & 3,44 & 0,00 & 0,00 & 0,00 & 8,66 & 100 \\
\hline 3 & 5200 & 41,91 & 22,38 & 27,85 & 0,00 & 0,00 & 2,92 & 0,00 & 0,00 & 0,00 & 4,94 & 100 \\
\hline 4 & 5360 & 25,59 & 27,80 & 21,71 & 3,36 & 1,97 & 2,19 & 3,75 & 7,15 & 0,00 & 6,48 & 100 \\
\hline 5 & 5380 & 28,27 & 30,08 & 22,81 & 5,63 & 1,88 & 3,20 & 2,40 & 0,00 & 0,00 & 5,72 & 100 \\
\hline 6 & 5400 & 29,97 & 26,17 & 24,86 & 4,98 & 0,00 & 3,46 & 4,12 & 4,26 & 0,00 & 2,18 & 100 \\
\hline 7 & 5410 & 33,00 & 27,31 & 22,34 & 4,59 & 2,61 & 2,71 & 0,00 & 2,65 & 0,00 & 4,78 & 100 \\
\hline 8 & 5420 & 32,73 & 26,07 & 17,60 & 7,97 & 0,00 & 2,89 & 2,83 & 2,79 & 0,00 & 7,13 & 100 \\
\hline
\end{tabular}

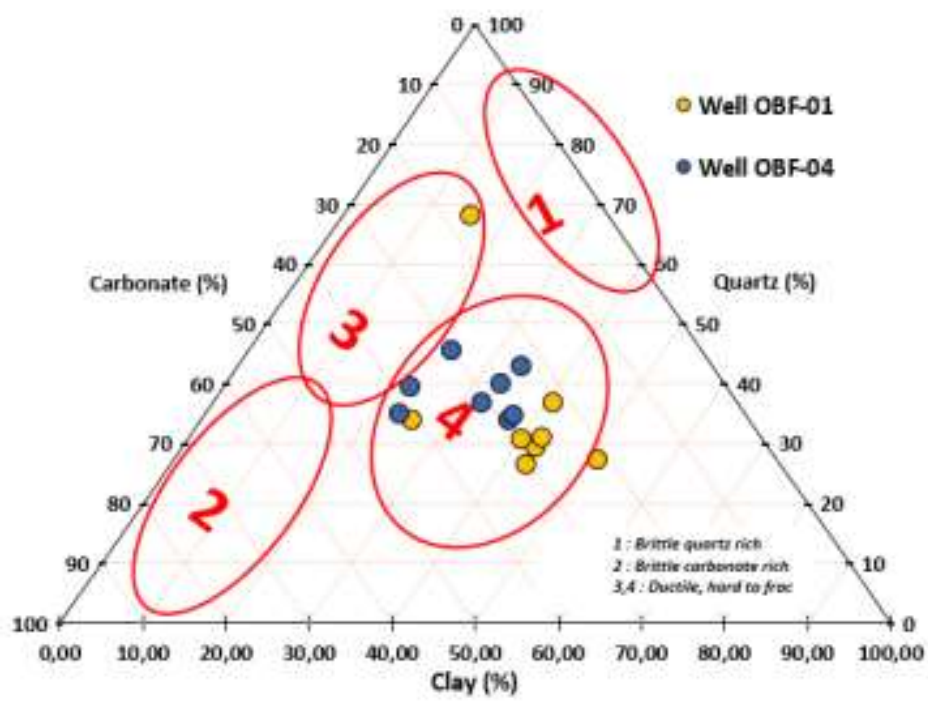

(Modified fram Bai, after 2016 Rickman, 2008)

Figure 2. Plot of the main mineral in ternary diagram from the results of the XRD analysis (bulk) of drill cutting samples OBF-01 and OBF-04 wells 


\subsection{Fracture Barrier Analysis of Well OBF-01:}

Figure 3 shows the plot of the results of XRD (bulk) analysis (Q-C-C and BI) from drill cutting samples of the Upper Baturaja Formation with a depth interval of 5120 - $5328 \mathrm{ft}$, where Calcite is the most dominant (31.39\% Avg), compared to Quartz $(30.49 \%$ Avg), and Clay $(22.43 \%$ Avg). Brittleness Index $(0.36)<0.48$, including rocks with the Ductile category (Perez \& Marfurt, 2013).

Figure 4 shows the plot of the results of the well $\log$ analysis (UCS, BI and FI) of the well OBF-01 from the Upper Baturaja Formation at the interval of $5120-5328 \mathrm{ft}$, where the Brittleness Index is generally $<0.48$, including rocks with the Ductile category (Perez \& Marfurt, 2013 ). In general, the Frability Index $<0.55$, is not fracable (hard to frac) or difficult to do hydraulic fracturing (Jin et al., 2014).

Figure 5 shows the correlation of the results of XRD analysis \& well log of well OBF-01 (Upper Baturaja Formation), it can be concluded that all depth intervals are fracture barriers. From the results of XRD (bulk analysis), with the predominance of Calcite (31.39\% Avg), the Upper Baturaja Formation for well stimulation, it is recommended to use acidizing or acid-fracturing (a combination of acidizing and fracturing).

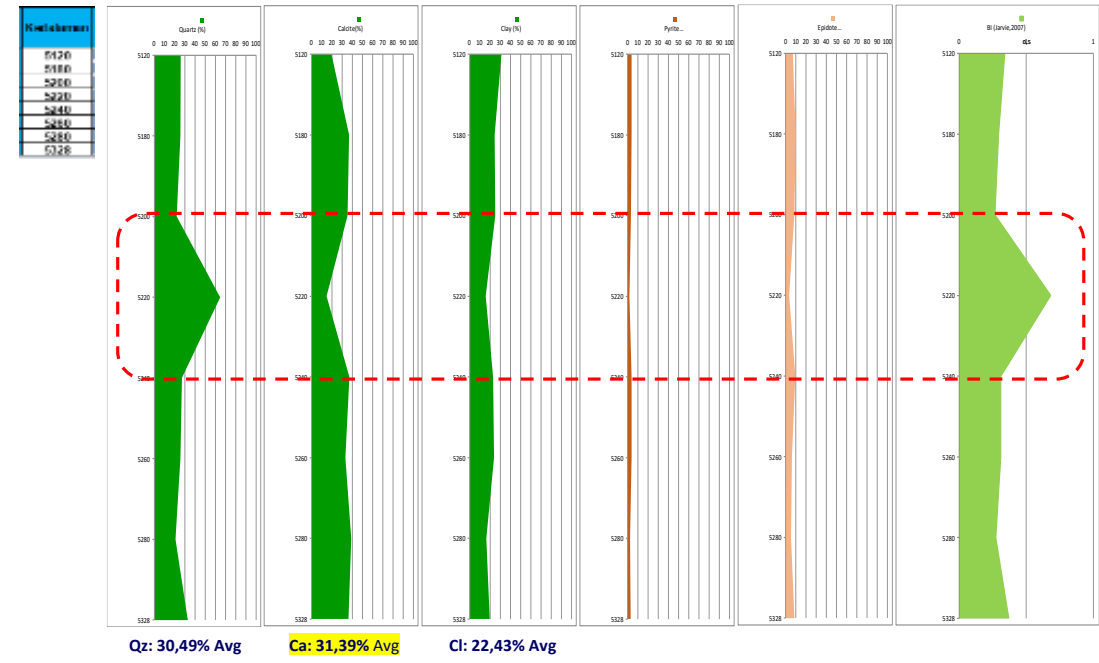

Figure 3. Plot of XRD Analysis (Bulk) Results of the Well OBF-01 of the Upper Baturaja Formation (5120 - $5328 \mathrm{ft}$ )
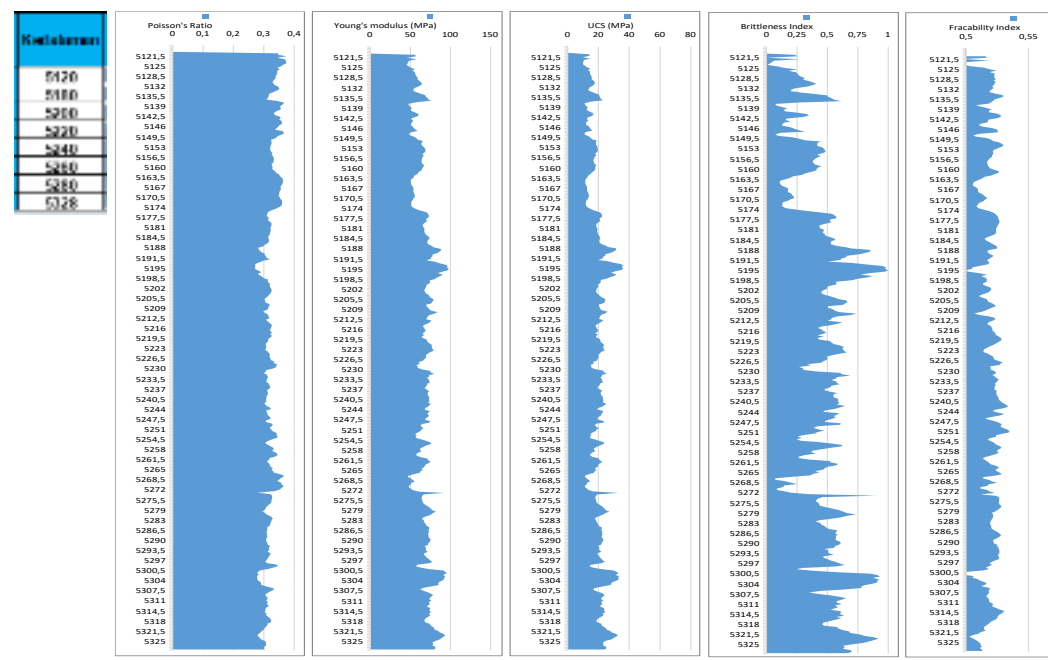

Figure 4. Well Log Analysis of the Well OBF-01 of the Upper Baturaja Formation (5120 - $5328 \mathrm{ft})$ 


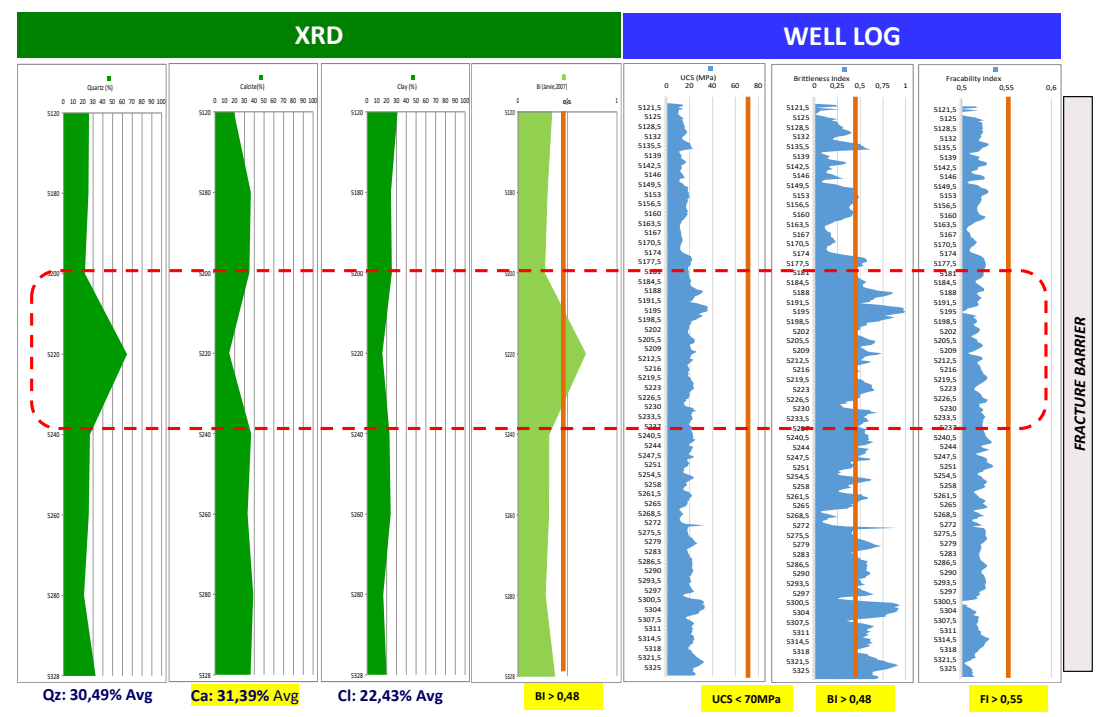

Figure 5. Correlation of XRD Analysis and Well Log of Well OBF-01, Upper Baturaja Formation

\subsection{Fracture Barrier Analysis of Well OBF-04:}

Figure 6 shows the plot of the results of XRD (bulk) analysis (Q-C-C and BI) for drill cutting samples of the Upper Baturaja Formation with a depth interval of $5160-5420 \mathrm{ft}$, where Quartz minerals are the most dominant (31.55\% Avg), compared to Clay $(25.31 \% \mathrm{Avg})$ and Calcite. $(24.97 \% \mathrm{Avg}$. Brittleness Index $(0.39 \mathrm{Avg})<0.48$, including rocks with the Ductile category (Perez \& Marfurt, 2013).

Figure 7 shows the plot of the results of well log analysis (UCS, BI and FI) of well OBF-04 in the Upper Baturaja Formation, the interval of $5160-5420 \mathrm{ft}$, where the Brittleness Index is generally $<0.48$, including rocks categorized as Ductile (Perez \& Marfurt, 2013). In general, the Frability Index $<0.55$, is not fracable (hard to frac) or difficult to do hydraulic fracturing (Jin et al., 2014).

Figure 8 shows the correlation of the results of XRD analysis \& well log of well OBF-04 (Upper Baturaja Formation), it can be concluded that all depth intervals are fracture barriers. From the results of the XRD (bulk analysis) test, with the predominance of Calcite (31.39\% Avg), the Upper Baturaja Formation for well stimulation, it is recommended to use acidizing (acidizing) or acid-fracturing (a combination of acidizing and fracturing).

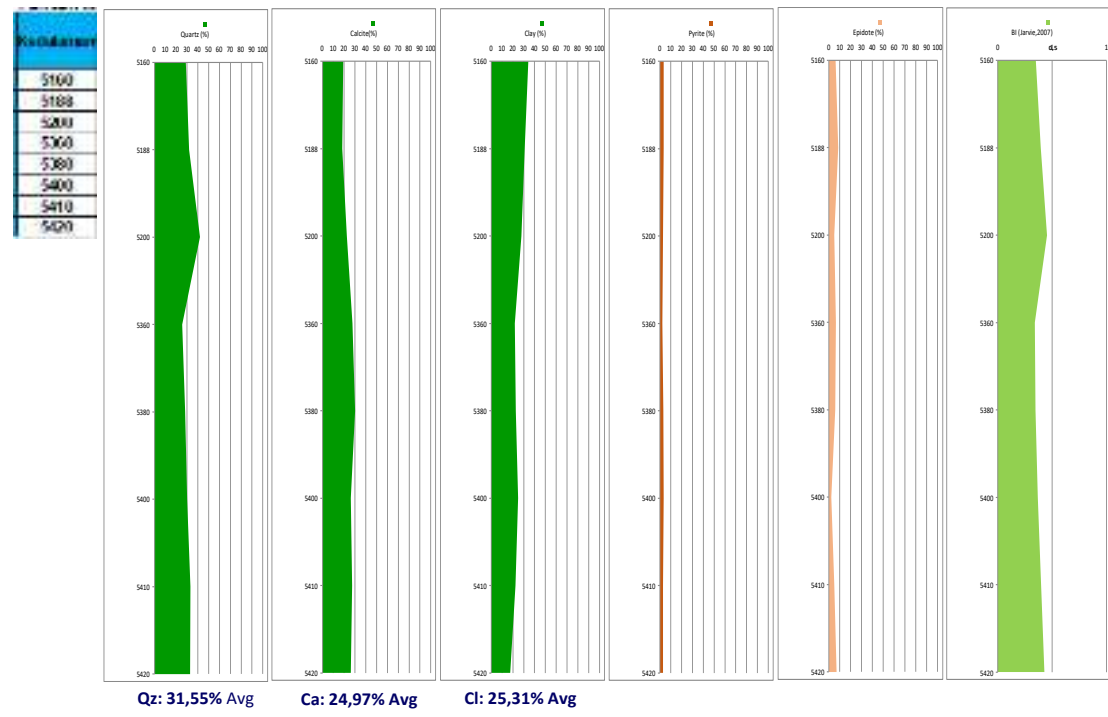

Figure 6. Plot of XRD (Bulk Analysis) Results of the Well OBF-04 of the Upper Baturaja Formation (5160 - $5420 \mathrm{ft}$ ) 

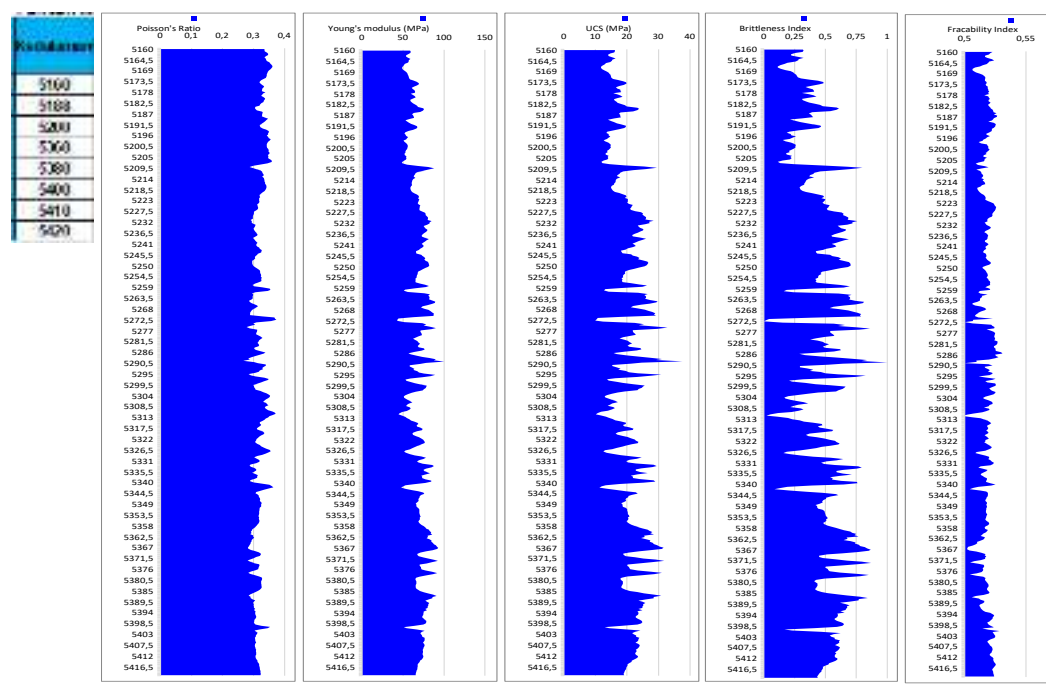

Figure 7. Well Log Analysis of the Well OBF-04 of the Upper Baturaja Formation $(5160-5420 \mathrm{ft})$

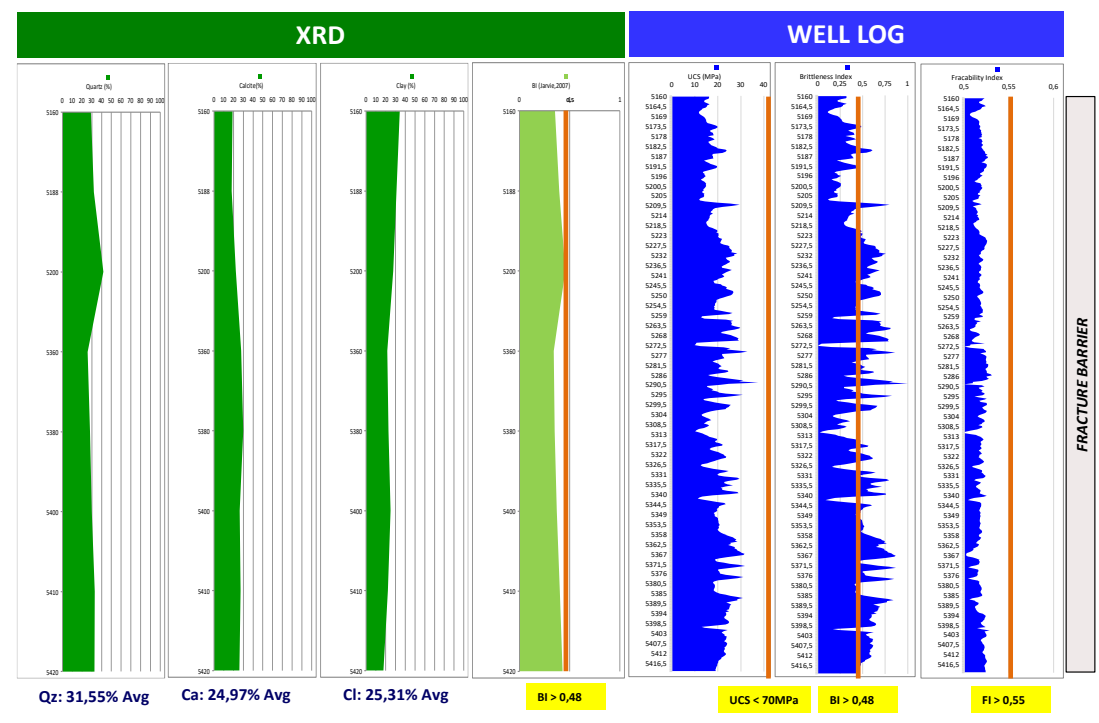

Figure 8. Correlation of XRD Analysis and Well Log of Well OBF-04, Upper Baturaja Formation

\subsection{Summary of Fracture Barrier Analysis Results}

In general, the results of bulk XRD analysis of cutting samples from OBF-01 and OBF-04 wells in the Upper Baturaja Formation (UBR), show that Calcite is the most dominant mineral compared to Quartz and Clay. Brittleness Index <0.48, including rocks with the Ductile category (Perez \& Marfurt, 2013).

In general, the results of well log analysis (UCS, BI and FI) of OBF-01 and OBF-04 wells in the Upper Baturaja Formation, Brittleness Index generally <0.48, including rocks with the Ductile category (Perez \& Marfurt, 2013). In general, the Frability Index $<0.55$, is not fracable (hard to frac) or difficult to do hydraulic fracturing (Jin et al., 2014).

Correlation of XRD analysis results and well logs of OBF-01 and OBF-04 wells (Upper Baturaja Formation), it can be concluded that all depth intervals are fracture barriers.

In general, the XRD test results (bulk analysis), with the predominance of Calcite minerals, the Upper Baturaja Formation for well stimulation, are recommended to use acidizing or acid-fracturing (a combination of acidizing and fracturing).

In fracture barrier analysis, the presence of minor minerals (Feldspar, Pyrite, Epidote, etc.) does not have a significant effect on the properties of the Upper Baturaja Formation. 


\section{CONCLUSION}

1. From the results of the XRD analysis (bulk), based on plot from the ternary diagram, it shows that the distribution of the main minerals (Quartz, Clay, and Calcite) is more dominant in the Ductile zone, hard to frac category. This indicates that all intervals in the OBF-01 and OBF-04 wells are more ductile, and hydraulic fracturing is not recommended. From the results of the bulk analysis, Calcite mineral is more dominant, so for well stimulation work it is recommended to use acidizing or acid fracturing.

2. In general, the results of XRD (bulk) analysis of drill cutting samples from the OBF-01 and OBF-04 wells in the Upper Baturaja Formation (UBR), show that Calcite mineral is the most dominant mineral compared to Quartz and Clay. Brittleness Index $<0.48$, including rocks with the Ductile category.

3. In general, the results of well log analysis (UCS, BI and FI) from the OBF-01 and OBF-04 wells in the Upper Baturaja Formation, Brittleness Index generally $<0.48$, including rocks with the Ductile category. Frability Index in general $<0.55$, is not fracable (hard to frac) or difficult to apply hydraulic fracturing.

4. Correlation of XRD and well log analysis results of the OBF-01 and OBF-04 wells (Upper Baturaja Formation), it can be concluded that all depth intervals are fracture barriers. In general, from the results of the XRD (bulk) analysis, with the predominance of Calcite mineral, it is recommended to use acidizing or acid-fracturing for well stimulation planning in the Upper Baturaja Formation.

\section{ACKNOWLEDGEMENTS}

The authors would like to thank UTC PT Pertamina (Persero) for providing assistance of XRD unit and cooperation to carry out the XRD analysis study of drill cuttings from all APH (Upstream Subsidiaries) at PT. Pertamina (Persero) which is very helpful for lecturers and students research.

\section{REFERENCES}

Amir, V., Achidat, R., Meirita, M., \& Guttormsen, J., 2011. Facies Architecture and Depositional Relationships of Batu Raja Carbonates in Letang, Rawa, and Tengah Fields, Corridor Block, South Sumatra: Proceedings Indonesian Petroleum Association, 35th Annual Convention \& Exhibition.

Bai, M., 2016. Why Are Brittleness and Fracability Not Equivalent in Designing Hydraulic Fracturing in Tight Shale Gas Reservoirs, Geomechanics Consultant, Houston, USA.

Bishop, M. G.,2001. South Sumatra BasinProvince, Indonesia: The Lahat/Talang Akar- Cenozoic Total Petroleum System, United States Geological Survey Open-File Report 99-50-S.

Bladh, 2001. Handbook of Mineralogy, Mineralogical Society of America, Chantilly, VA 20151-1110, USA.

Bragg, 1913. The Reflection of X-rays by Crystals.

Castagna et al., 1985. Relationships between compressional-wave and shear-wave velocities in clastic silicate rocks, GEOPHYSICS (1985),50(4):571.

Chong et al., 2010. A Completions Guide Book to Shale-Play Development: A Review of Successful Approaches toward Shale-Play Stimulation in the Last Two Decade.

Fjaer, 2008. Static and Dynamic Moduli of a weak Sandstone.

Grieser and Bray (2007). Identification of Production Potential in Unconventional Reservoirs.

Hall, R., 2002. Cenozoic geological and plate tectonic evolution of SE Asia and the SW Pacific: Computer- based reconstructions, model and animations. Journal of Asian East Sciences. Volume 20, No. 4, April 2002.

Jarvie, 2007. Unconventional Shale-Gas Systems: The Mississippian Barnett Shale Of North-Central Texas As One Model For Thermogenic Shale-Gas Assessment, AAPG Bulletin, April 2007, ReseachGate.

Kahraman, 2007. The correlations between the saturated and dry P-wave velocity of rocks, Elsevier.

Li Jinbu et al., 2015. Fracability Evaluation of the Unconventional Mud-Shale Reservoir, University of Petroleum (East China), Shandong, China.

Lili Sui et al., 2015. Comprehensive Evaluation on Shale Fracability Using Principal Component Analysis, Dongying depression Shengli Oilfield, China.

Lobo, C. et al., 2017. Methodology for Petrophysical and Geomechanical Analysis of Shale Plays, Case Study: La Luna and Capacho Formation, Maracaibo Basin.

Maryanto, S., 2007. Petrografi dan Proses Diagenesis Batugamping Formasi Baturaja di Lintasan Air Saka, OKU Selatan, Sumatera Selatan. Jurnal Sumber Daya Geologi, 17 (1), p.13-31.

Perez, R. and Marfurt, K., 2013. Calibration of Brittleness to Elastic Rock Properties via Mineralogy Logs in Unconventional Reservoirs, University of Oklahoma, Norman, Oklahoma.

Sanchez V.D. C., Danudjaja S., 2013. Impact of Depositional Facies on the Spatial Distribution of Reservoir Quality in the Batu Raja Carbonates of the Corridor Block, South Sumatra. Proceedings Indonesian Petroleum Association, $37^{\text {th }}$ Annual Convention \& Exhibition.

Wilson, J.L., 19. Carbonate Facies in Geologic History. Springer-Verlag. New York, Heidel- berg, Berlin, 471pp. 
Xiaochun Jin et al., 2014. Fracability Evaluation in Shale Reservoirs - An Integrated Petrophysics and Geomechanics Approach, Article in SPE Journal, February 2014.

Yuan et al., 2017. An Improved Fracability-Evaluation Method for Shale Reservoir Based on New Fracture ToughnessPrediction Models, SPE-185963-PA.

Zhang L., 2016. Engineering Properties of Rocks, University of Arizona, Tuscon, Arizona, USA.

Zoback, 2008. Reservoir Geomechanics In Situ Stress and Rock Mechanics Applied to Reservoir Processes, Department of Geophysics, Stanford University, USA. 